\title{
Model Pembelajaran Find Someone Who dan Timed Pair Share untuk Meningkatkan Motivasi dan Hasil Belajar IPS
}

\author{
Firsa Fajar Mahardika ${ }^{1}$, Budi Eko Soetjipto ${ }^{2}$, Siti Malikhah Towaf ${ }^{3}$ \\ ${ }^{1}$ Pendidikan Dasar-Universitas Negeri Malang \\ ${ }^{2}$ Manajemen-Universitas Negeri Malang \\ ${ }^{3}$ Pendidikan Ilmu Pengetauhan Sosial-Universitas Negeri Malang
}

\begin{tabular}{l}
\hline \hline INFO ARTIKEL \\
\hline Riwayat Artikel: \\
Diterima: 09-04-2019 \\
Disetujui: 23-06-2019 \\
\hline
\end{tabular}

Kata kunci:

learning model; motivation;

learning outcomes;

model pembelajaran;

motivasi;

hasil belajar

\author{
Alamat Korespondensi: \\ Firsa Fajar Mahardika \\ Pendidikan Dasar \\ Universitas Negeri Malang \\ Jalan Semarang 5 Malang \\ E-mail: firsamahardika@gmail.com
}

\begin{abstract}
ABSTRAK
Abstract: This study aims to describe the application of the Find Someone Who and Timed Pair Share learning models to improve social studies motivation and learning outcomes. The type of research used is Class Action Research. The subject of this study was the VB class of SDN Pakunden 2 with 37 students. The results of this study that the application of the Find Someone Who and Timed Pair Share learning models can increase the motivation and learning outcomes of social studies. At the end of the second cycle, all indicators assessed were able to exceed the specified success criteria.

Abstrak: Penelitian ini bertujuan untuk mendeskripsikan penerapan model pembelajaran Find Someone Who dan Timed Pair Share untuk meningkatkan motivasi dan hasil belajar IPS. Jenis penelitian yang digunakan adalah Penelitian Tindakan Kelas. Subjek penelitian ini adalah kelas VB SDN Pakunden 2 dengan jumlah 37 siswa. Hasil dari penelitian ini bahwa penerapan model pembelajaran Find Someone Who dan Timed Pair Share dapat meningkatkan motivasi dan hasil belajar IPS. Pada akhir siklus II, seluruh indikator yang dinilai mampu melampaui kriteria keberhasilan yang ditetapkan.
\end{abstract}

Motivasi adalah proses dalam diri siswa untuk mendorong siswa menumbuhkan dan mempertahankan suatu aktivitas sesuai dengan tujuan yang telah disusun. Motivasi memiliki peran yang penting dalam belajar. Ozturk, \& Akkas (2013) berpendapat bahwa motivasi sebagai pendorong siswa untuk memulai aktivitas belajar, dorongan untuk rasa ingin tahu dan berprestasi. Dengan demikian, motivasi memiliki peran yang penting dalam suatu keberhasilan pembelajaran. Hasil belajar akan tercapai sesuai yang diharapkan jika ada motivasi yang tepat dalam diri siswa untuk belajar. Tugas guru harus menumbuhkan dan mempertahankan motivasi belajar. Christophel (1990) berpendapat bahwa guru memiliki peran untuk menumbuhkan dan mempertahankan motivasi siswa dalam belajar. Guru perlu memfasilitasi siswa untuk menumbuhkan motivasi dengan cara menerapkan model pembelajaran yang membuat siswa aktif dan bertanggung jawab terhadap belajar (Scharle \& Szabo, 2005). Siswa yang memiliki motivasi dalam belajar menurut Schunk (2012) akan (1) serius dalam mencari informasi materi pembelajaran, (2) siswa mendengar dengan seksama informasi pengetauhan dari teman, (3) siswa bertanya pada guru dan teman apabila materi yang belum siswa pahami, dan (4) siswa akan berusaha menghafal materi yang diajarkan .

Berdasarkan observasi awal di kelas VB didapatkan informasi bahwa dalam pembelajarannya guru dominan menggunakan ceramah. Keadaan ini membuat siswa melakukan kegiatan di luar aktivitas pembelajaran seperti siswa yang berbicara dengan temanya yang tidak ada kaitannya dengan materi pembelajaran maupun bermain dengan benda di sekitarnya. Siswa terlihat kurang antusias ketika diajar menggunakan metode ceramah. Pada kegiatan bertanya jawab dengan guru, siswa menjawab pertanyaan secara serempak dengan suara yang pelan dan ragu-ragu. Pada saat guru memberikan tugas kepada siswa, siswa terlihat malas dan menunda pekerjaan. Banyak siswa yang belum selesai mengerjakan ketika waktu yang ditentukan guru sudah berakhir. Siswa pada akhirnya mengandalkan pembahasan jawaban dari guru.

Ilmu Pengetauhan Sosial merupakan salah satu muatan yang hingga sekarang diajarkan pada jenjang sekolah dasar. IPS menurut Gunawan (2013) adalah kumpulan informasi yang diorganisasikan secara terpadu dari displin ilmu geografi, sosiologi, antropologi, dan ekonomi. Berdasarkan hasil wawancara dengan siswa SDN Pakunden 2 mengenai pembelajaran IPS adalah pembelajaran yang menuntut harus menghafal banyak materi sehingga sebagian besar siswa mengalami kesulitan. Berdasarkan hasil wawancara dengan guru mengenai IPS bahwa pembelajaran IPS memang harus diajarkan menggunakan metode ceramah dan pemberian tugas untuk efisiensi waktu dikarenakan banyaknya materi IPS yang diajarkan. 
Hasil angket motivasi pada pratindakan mencapai 58,3\%, sedangkan nilai hasil belajar IPS pratindakan mencapai $40 \%$ dengan rincian 15 siswa yang melampaui KBM dan 22 siswa yang tidak melampaui KBM. Ketuntasan Belajar Minimal yang ditetapkan oleh SDN Pakunden 2 untuk muatan IPS sebesar 75. Rendahnya motivasi dan hasil belajar IPS disebabkan metode yang diajarkan guru kurang menarik perhatian siswa. Guru belum memberikan kesempatan siswa aktif secara merata. Rendahnya motivasi dan hasil belajar perlu segera diperbaiki dengan model pembelajaran yang menempatkan siswa sebagai subyek belajar. Pembelajaran kooperatif adalah salah satu pembelajaran yang mampu mengaktifkan siswa dalam belajar. Kim, dkk (2012) mendefinisikan pembelajaran kooperatif sebagai situasi pembelajaran dimana siswa saling mendorong untuk melakukan upaya terbaik dalam kelompok kecil untuk mencapai tujuan individu dan kelompok.

Keuntungan menerapkan pembelajaran kooperatif seperti yang diungkapkan oleh Wang (2012) yang berpendapat bahwa dampak positif menerapkan pembelajaran kooperatif membuat pembelajaran menjadi menyenangkan bagi siswa. Hal tersebut karena siswa mendapatkan pengalaman-pengalaman baru dari interaksi dengan temannya. Siswa termotivasi untuk menggali lebih banyak pengetauhan. Goodyear, dkk (2014) dalam penelitiannya menyebutkan bahwa penerapan pembelajaran kooperatif mampu meningkatkan self esteem dan motivasi belajar siswa. Yamarik (2007) berpendapat bahwa pembelajaran kooperatif membantu siswa yang berprestasi rendah untuk memahami materi pembelajaran, sedangkan pembelajaran kooperatif bagi siswa yang berprestasi tinggi membantu meningkatkan ketrampilan berkomunikasi Prinsip pembelajaran kooperatif menurut Kagan \& Kagan (2009) antara lain (1) sikap menciptakan dukungan yang saling menguntungkan antar siswa, (2) tanggung jawab pribadi, (3) partisipasi yang sama untuk semua siswa, dan (4) interaksi bersamaan.

Pembelajaran kooperatif memiliki banyak tipe. Peneliti memilih menggunakan model pembelajaran kooperatif jenis Find Someone Who dan Timed Pair Share. Model pembelajaran Find Someone Who menurut Kagan \& Kagan (2009) adalah model kooperatif yang mengharuskan siswa mencari pasangan di luar kelompoknya untuk menjawab pertanyaan-pertanyaan dari guru. Langkah-langkah model pembelajaran Find Someone Who menurut Kagan \& Kagan (2009) adalah (1) siswa mengangkat tangannya untuk mencari pasangan dari kelompok lain, (2) dalam keadaan berpasangan, siswa A membaca pertanyaan dari lembar kerjanya kepada siswa B, siswa B menjawab pertanyaan yang diajukan. Siswa A mencatat jawaban di lembar kerjanya dan memberikan pujian, (3) siswa B mengecek dan menilai jawaban, (4) siswa B membaca pertanyaan dari lembar kerjanya kepada siswa A, siswa A menjawab pertanyaan yang diajukan. Siswa A mencatat jawaban dilembar kerjanya dan memberikan pujian, (5) siswa A mengecek dan menilai jawaban, (5) setelah siswa saling membacakan pertanyaan dan menjawab, siswa saling berjabat tangan, berpisah, dan mengangkat tangan untuk membentuk pasangan yang baru, (7) siswa mengulangi langkah 1-6 hingga lembar kerja terisi seluruhnya, (8) ketika lembar kerja seluruhnya terisi, siswa kembali kepada kelompok asal. Siswa boleh didekati oleh teman yang lain sebagai rujukan, (9) di dalam kelompok, siswa diharuskan saling membandingkan jawaban antar anggota dalam satu kelompok. Jika ditemukan jawaban yang menyebabkan keraguan. Maka seluruh anggota dalam suatu kelompok diperbolehkan mengangkat tangan mereka untuk bertanya kepada guru. Kelebihan model pembelajaran Find Someone Who menurut Kurnia, dkk (2017) membuat pembelajaran tidak membosankan, meningkatkan kerjasama, dan memotivasi siswa.

Model pembelajaran Timed Pair Share menurut Kagan \& Kagan (2009) adalah model kooperatif yang melibatkan interaksi siswa secara berpasangan dimana siswa saling berbagi informasi dengan pasangan didalam kelompoknya dengan waktu yang telah ditentukan. Waktu yang ditentukan untuk berbagi informasi dari siswa A ke siswa B sebanyak tiga menit (maupun sebaliknya). Langkah-langkah model pembelajaran Timed Pair Share adalah (1) guru mengumumkan topik atau pertanyaan. Guru menentukan berapa lama siswa saling berbagi. Guru menyediakan waktu untuk siswa berpikir dan menulis jawaban atas pertanyaan yang diajukan oleh guru, (2) secara berpasangan, siswa A menyampaikan pendapat kepada siswa B, siswa B mendengarkan, (3) siswa B merepon dengan respon yang positif, dan (4) siswa saling berganti peran. Kelebihan model pembelajaran Timed Pair Share menurut Kagan \& Kagan (2009) adalah melatih berkomunikasi antar sesama siswa dan membangun pengetauhan

Penelitian sebelumnya yang dari Kurnia, dkk (2017) menunjukan bahwa penerapan model Find Someone Who dan Two Stay Two Stray dapat meningkatkan efikasi diri dan hasil belajar IPS. Penelitian Marlina, dkk (2016) menunjukan bahwa penerapan model pembelajaran Rally Coach dan Find Someone Who dapat meningkatkan keterampilan sosial dan hasil belajar. Penelitian Nurhaniyah, dkk (2015) menunjukan bahwa penerapan model Find Someone Who dipadukan dengan Flashcard dapat meningkatkan motivasi belajar siswa. Tujuan dari penelitian adalah untuk mendeskripsikan penerapan model pembelajaran Find Someone Who dan Timed Pair Share untuk meningkatkan motivasi dan hasil belajar kelas V SD

\section{METODE}

Penelitian yang dilaksanakan menggunakan Penelitian Tindakan Kelas. Penelitian ini terdiri dari dua siklus. Setiap siklus terdiri atas empat pertemuan. Pelaksanaan model pembelajaran Find Someone Who dan Timed Pair Share dilaksanakan secara bergantian. Pada pertemuan pertama menggunakan model Find Someone Who, pada pertemuan kedua menggunakan model pembelajaran Timed Pair Share dan seterusnya. Penelitian Tindakan Kelas menggunakan model dari Kemmis \& McTaggart (1988). Langkah-langkah penelitian menurut Kemmis \& McTaggart (1988) adalah perencanaan, pelaksanaan, observasi, dan refleksi. Peran peneliti sebagai perencanan tindakan dan mengimplemtasikan perencanaan tindakan dengan mengajar dikelas VB. Peneliti dibantu dua observer, yaitu guru kelas VB dan seorang guru dari SDN Pakunden 2. Penelitian 
dilaksanakan dikelas VB SDN Pakunden 2 Kota Blitar tahun ajaran 2018/2019 dengan jumlah siswa sebanyak 37 siswa. Data dan sumber data dijelaskan pada tabel 1 .

Tabel 1. Data dan Sumber Data

\begin{tabular}{llcc}
\hline \multicolumn{1}{c}{ Data } & \multicolumn{1}{c}{ Instrumen } & Teknik Pengambilan Data & Sumber Data \\
\hline Keterlaksanaan Aktivitas Guru & Lembar Observasi Aktivitas Guru & Observasi & Guru \\
\hline Keterlaksanaan Aktivitas Siswa & Lembar Observasi Aktivitas Siswa & Observasi & Siswa \\
\hline Catatan Lapangan & Lembar Observasi Catatan Lapangan & Observasi & Guru dan Siswa \\
\hline Respon siswa setelah tindakan & Pedoman wawancara respon siswa & Wawancara & Siswa \\
\hline Motivasi & Pedoman Observasi Motivasi & Observasi & Siswa \\
& Angket Motivasi & Angket & Siswa \\
\hline Hasil Belajar & Tes & Tes Tulis & Siswa \\
\hline
\end{tabular}

Proses pengumpulan data dengan menggunakan lembar observasi aktivitas guru, lembar observasi aktivitas siswa, lembar observasi motivasi, catatan lapangan, wawancara, tes tulis, dokumentasi dan pemberian angket motivasi. Teknik analisis data menurut Milles \& Hubberman (1992) melalui langkah-langkah yaitu (1) reduksi data, penyajian data, dan penarikan kesimpulan. Dirumuskan pedoman kriteria keberhasilan untuk mengevaluasi sejauh mana tingkat keberhasilan tindakan dalam suatu siklus. Berikut dijelaskan dalam tabel 2 .

Tabel 2. Kriteria Keberhasilan yang Ditetapkan

\begin{tabular}{cc}
\hline Aspek yang dinilai & Kriteria keberhasilan \\
\hline Hasil keterlaksanaan Pembelajaran oleh Guru & $\geq 80 \%$ \\
\hline Hasil keterlaksaanaan pembelajaran oleh siswa & $\geq 80 \%$ \\
\hline Hasil observasi motivasi & $\geq 80 \%$ \\
\hline Hasil angket motivasi & $\geq 80 \%$ \\
\hline Hasil belajar klasikal & $\geq 80 \%$ \\
\hline
\end{tabular}

HASIL

Penelitian yang telah dilaksanakan terdiri dari dua siklus. Hasil penelitian menunjukkan bahwa penerapan model pembelajaran Find Someone Who dan Timed Pair Share mampu dilaksanakan secara baik oleh guru dan siswa. Hal ini berdampak positif terjadinya peningkatkan motivasi dan hasil belajar IPS. Rincian hasil penelitian dijelaskan pada tabel 3, 4, 5, dan gambar 1.

Tabel 3. Peningkatan Keterlaksanaan Pembelajaran oleh Guru

\begin{tabular}{cccc}
\hline Pembelajaran & Hasil & Kategori & Peningkatan \\
\hline Siklus 1 & $73,4 \%$ & Baik & $15,6 \%$ \\
\cline { 1 - 3 } Siklus 2 & $88,9 \%$ & Sangat Baik & \\
\hline
\end{tabular}

Dari tabel 3 dijelaskan bahwa hasil keterlaksanaan pembelajaran oleh guru pada siklus 1 mencapai $73,4 \%$ yang dikategorikan baik. Hasil keterlaksanaan pembelajaran oleh guru pada siklus 2 mencapai 88,9\% dikategorikan sangat baik. Dengan demikian hasil aktivitas guru pada siklus 2 lebih baik daripada siklus 1 . Terjadi peningkatan sebanyak $15,6 \%$.

Tabel 4. Peningkatan Keterlaksanaan Pembelajaran oleh Siswa

\begin{tabular}{cccc}
\hline Pembelajaran & Hasil & Kategori & Peningkatan \\
\cline { 1 - 3 } Siklus 1 & $71 \%$ & Baik & $16,3 \%$ \\
\cline { 1 - 3 } Siklus 2 & $87,3 \%$ & Sangat Baik & \\
\hline
\end{tabular}

Dari tabel 4 dijelaskan bahwa hasil keterlaksanaan pembelajaran oleh siswa pada siklus 1 mencapai $71 \%$ yang dikategorikan baik. Hasil keterlaksanaan pembelajaran oleh siswa pada siklus 2 mencapai 87,3\% dikategorikan sangat baik. Dengan demikian hasil aktivitas siswa pada siklus II lebih baik daripada siklus 1 . Terjadi peningkatan sebanyak $16,3 \%$.

Tabel 5. Peningkatan Observasi Motivasi

\begin{tabular}{cccc}
\hline Pembelajaran & Hasil & Kategori & Peningkatan \\
\hline Siklus 1 & $71,5 \%$ & Baik & $13,2 \%$ \\
\cline { 1 - 3 } Siklus 2 & $84,7 \%$ & Sangat Baik & \\
\hline
\end{tabular}


Dari gambar 1 dijelaskan bahwa hasil observasi motivasi pada siklus I mencapai 71,5\% yang dikategorikan baik. Hasil observasi motivasi pada siklus II mencapai 84,7\% dikategorikan sangat baik. Dengan demikian hasil aktivitas siswa pada siklus II lebih baik daripada siklus I. Terjadi peningkatan sebanyak 13,2\%.

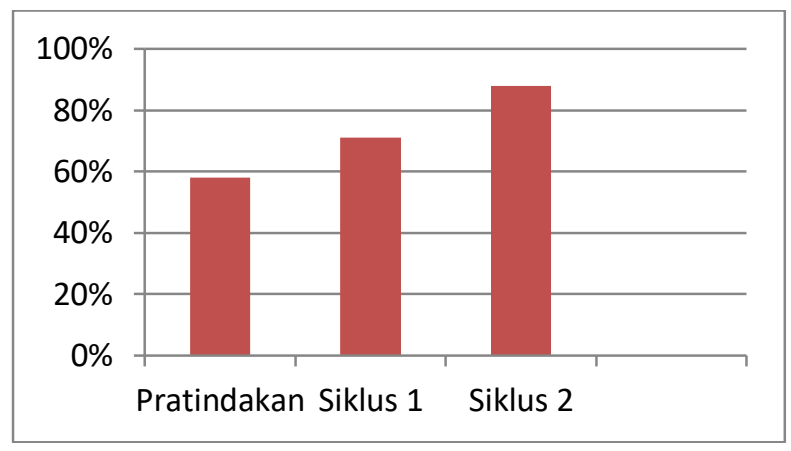

\section{Gambar 1. Peningkatan Angket Motivasi Belajar}

Dari gambar 1 dijelaskan bahwa hasil angket motivasi pada pratindakan mencapai 58,3\% yang dikategorikan sedang. Hasil observasi motivasi pada siklus I mencapai 75,1\% dikategorikan baik. Dengan demikian, hasil observasi motivasi pada siklus I lebih baik daripada pratindakan. Terjadi peningkatan nilai angket motivasi dari pratindakan ke siklus I sebanyak 16,8\%. Hasil observasi motivasi pada siklus II mencapai $88,2 \%$ dikategorikan baik. Dengan demikian, hasil observasi motivasi pada siklus II lebih baik daripada siklus I. Terjadi peningkatan nilai angket motivasi dari siklus I ke siklus II sebanyak $13,1 \%$.

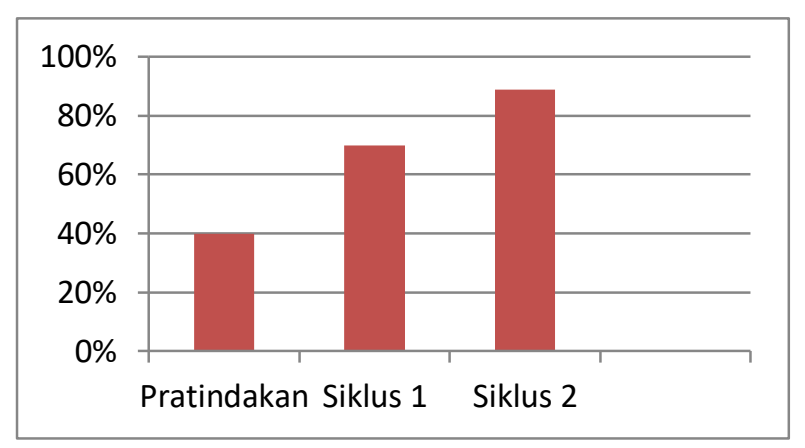

\section{Gambar 2. Peningkatan Hasil Belajar IPS}

Dari gambar 2 dijelaskan bahwa hasil belajar IPS pada pratindakan mencapai $40 \%$ yang dikategorikan kurang. Hasil belajar IPS pada siklus I mencapai 70\% dikategorikan baik. Dengan demikian hasil belajar IPS pada siklus I lebih baik daripada pratindakan. Terjadi peningkatan nilai hasil belajar IPS dari pratindakan ke siklus I sebanyak 30\%. Hasil belajar IPS pada siklus II mencapai 89\% dikategorikan baik. Dengan demikian, hasil belajar IPS pada siklus II lebih baik daripada siklus II. Terjadi peningkatan nilai hasil belajar dari siklus I ke siklus II sebanyak $19 \%$.

\section{PEMBAHASAN}

Implementasi Model Pembelajaran Find Someone Who Dan Timed Pair Share dalam Pembelajaran IPS

Penelitian yang telah dilaksanakan menggunakan pembelajaran Kooperatif. Pembelajaran Kooperatif menurut Kim (2012) adalah situasi pembelajaran dimana siswa saling mendorong untuk melakukan upaya terbaik dalam kelompok kecil untuk mencapai tujuan individu dan kelompok. Model pembelajaran Find Someone Who dan Timed Pair Share termasuk ke dalam jenis pembelajaran kooperatif. Model pembelajaran Find Someone Who menurut Kagan \& Kagan (2009) adalah model kooperatif yang mengharuskan siswa mencari pasangan diluar kelompoknya untuk menjawab pertanyaan-pertanyaan dari guru. Model pembelajaran Timed Pair Share menurut Kagan \& Kagan (2009) adalah model kooperatif yang melibatkan interaksi siswa secara berpasangan dimana siswa saling berbagi informasi dengan pasangan didalam kelompoknya dengan waktu yang telah ditentukan. Langkah pertama dalam melaksanakan model pembelajaran adalah guru membagi kelas dengan kelompokkelompok kecil yang berjumlahkan empat hingga lima orang dengan pertimbangan jenis kelamin dan prestasi belajar. 
Penerapan model pembelajaran Find Someone Who dan Timed Pair Share bagi siswa SDN Pakunden 2 Kota Blitar adalah pengalaman baru yang menantang dan menarik bagi siswa. Penerapan model Find Someone Who dan Timed Pair Share membuat siswa berlatih mengungkapkan pendapat, mendengarkan pendapat, memberi pujian kepada teman, dan kerjasama . Dalam temuan penelitian mengenai penerapan model pembelajaran Find Someone Who dan Timed Pair Share bahwa tidak ada siswa yang mendominasi dalam kelompok. Semua siswa aktif bertukar informasi dengan frekuensi yang setara. Semua siswa diuntungkan ketika belajar menggunakan struktur pembelajaran kooperatif. Situasi ini sesuai dengan pendapat Kagan \& Kagan, (2009) yang menyatakan bahwa prinsip pembelajaran kooperatif didasarkan atas (1) sikap menciptakan dukungan yang saling menguntungkan antar siswa, (2) tanggung jawab pribadi, (3) partisipasi yang sama untuk semua siswa, dan (4) interaksi bersamaan.

Alat yang digunakan untuk mengukur pelaksanaan model pembelajaran Find Somenone Who dan Timed Pair Share menggunakan pedoman instrumen observasi. Instrumen observasi yang dimaksud adalah lembar observasi keterlaksanaan pembelajaran oleh guru dan lembar observasi keterlaksanaan pembelajaran oleh siswa. Hasil keterlaksanaan pembelajaran oleh guru pada siklus I mencapai 73,4\% dengan kategori baik. Keterlaksanaan pembelajaran oleh guru pada siklus I belum mencapai kriteria keberhasilan yang ditetapkan yaitu $\geq 80 \%$. Keterlaksanaan pembelajaran oleh guru pada siklus II mencapai $88,9 \%$ dengan kategori sangat baik. Hasil keterlaksanaan pembelajaran oleh guru pada siklus II mengalami peningkatan daripada siklus Idengan kenaikan sebesar 15,6\%. Hasil ketelaksanaan pembelajaran oleh guru pada siklus II menunjukkan keberhasilan dalam penelitian yang dilaksanakan karena telah mencapai target kriteria keberhasilan yang ditetapkan.

Hasil keterlaksanaan pembelajaran oleh siswa pada siklus I mencapai $71 \%$ dengan kategori baik. Keterlaksanaan pembelajaran oleh siswa pada siklus I belum mencapai kriteria keberhasilan yang ditetapkan yaitu $\geq 80 \%$. Keterlaksanaan pembelajaran oleh siswa pada siklus II mencapai 88,9\% dengan kategori sangat baik. Hasil keterlaksanaan pembelajaran oleh siswa pada siklus II mengalami peningkatan daripada siklus I dengan kenaikan sebesar 15,6\%. Hasil ketelaksanaan pembelajaran oleh siswa pada siklus II menunjukkan keberhasilan dalam penelitian yang dilaksanakan karena telah mencapai target kriteria keberhasilan yang ditetapkan.

Model pembelajaran Find Someone Who dan Timed Pair Share sudah dilaksanakan dengan baik oleh guru maupun siswa. Tetapi nilai hasil keterlaksanaan pembelajaran oleh guru dan siswa pada siklus I belum memenuhi kriteria keberhasilan yang ditetapkan. Dalam pelaksanaan model pembelajaran Find Someone Who dan Timed Pair Share belum optimal karena ditemukan beberapa permasalahan. Terdapat siswa masih belum paham, merasa kesulitan, serta masih salah dalam menerapkan langkah-langkah model pembelajaran Find Someone Who dan Timed Pair Share. Beberapa siswa yang tidak memberikan pujian atau umpan balik yang postif kepada temannya. Terdapat siswa yang kurang percaya diri dan malas dalam membandingkan materi. Hal tersebut dikarena siswa masih beradaptasi suasana pembentukan kelompok oleh guru. Keadaan kelas yang masih ramai saat proses membacakan jawaban kepada teman saat pelaksanaan model pembelajaran membuat siswa sulit berkonsentrasi dalam memproses materi yang dipelajari.

Hasil observasi keterlaksanaan pembelajaran oleh guru dan siswa pada pelaksanaan siklus II mengalami peningkatan daripada siklus I dikarenakan proses perbaikan pembelajaran pada siklus II. Rencana perbaikan pembelajaran pada siklus II berasal dari refleksi siklus I. Pada siklus II, guru menjelaskan kembali langkah-langkah pembelajaran terutama pada bagian yang masih salah. Guru memberikan bimbingan kepada kelompok secara berkelanjutan. Guru membimbing siswa untuk menciptakan suasana kelas yang kondusif saat bertukar informasi. Situasi kelas yang kondusif bermanfaat menambah konsentrasi siswa dalam memahami materi pembelajaran. Effendi, dkk (2016) berpendapat bahwa proses pembimbingan belajar oleh guru dapat memperkuat hubungan antara guru dan siswa menjadi lebih dekat. Guru memberikan dorongan semangat, memberikan penguatan jawaban dan mendorong tanggung jawab siswa untuk menyelesaikan pekerjaannya. Purwaningrum, dkk (2017) berpendapat bahwa peran guru menjadi penting dalam pembelajaran kooperatif untuk memandu siswa dalam belajar, memberikan respon positif, memberikan revisi jawaban siswa serta memotivasi siswa sehingga pelaksanaan siswa siklus II meningkat daripada siklus I.

\section{Implementasi Model Pembelajaran Find Someone Who Dan Timed Pair Share untuk Meningkatkan Motivasi Belajar}

Motivasi merupakan faktor yang menentukan kesuksesan dan kegagalan dalam mencapai tujuan belajar. Motivasi belajar siswa pada penelitian ini diukur dengan instrumen lembar observasi motivasi dan angket motivasi belajar. Lembar observasi motivasi diisi oleh observer pada setiap pembelajaran disemua siklus. Sedangkan angket motivasi diisi oleh seluruh siswa pada setiap akhir siklus. Terdapat empat aspek yang diamati dan dinilai untuk mengukur motivasi menurut Keller (2010) yang terdiri atas perhatian, keterkaitan, percaya diri, dan kepuasan.

Hasil angket motivasi belajar pada pratindakan mencapai $58.3 \%$ dengan kategori sedang. Hasil angket motivasi pratindakan belum mencapai kriteria keberhasilan yang ditetapkan yaitu $\geq 80 \%$. Hasil angket motivasi belajar pada siklus I mencapai $75,1 \%$ dengan kategori baik. Hasil angket motivasi pada siklus I mengalami peningkatan daripada angket motivasi pratindakan dengan kenaikan sebesar 16,8\%. Hasil angket motivasi pada siklus I belum mencapai kriteria keberhasilan yang ditetapkan. Hasil angket motivasi pada siklus II mencapai 88,2\% dengan kategori sangat baik. Hasil angket motivasi pada siklus II mengalami peningkatan daripada siklus I dengan kenaikan sebesar 13,1\%. Hasil angket motivasi pada siklus II menunjukkan keberhasilan dalam penelitian yang dilaksanakan karena telah mencapai target kriteria keberhasilan yang ditetapkan. 
Hasil observasi pada siklus I mencapai 71,5\% dengan kategori baik. Hasil observasi pada siklus I belum mencapai kriteria keberhasilan yang ditetapkan yaitu $\geq 80 \%$. Hasil observasi pada siklus II mencapai $84,7 \%$ dengan kategori sangat baik. Hasil observasi motivasi pada siklus II mengalami peningkatan daripada siklus I dengan kenaikan sebesar 13,2\%. Hasil observasi motivasi pada siklus II menunjukkan keberhasilan dalam penelitian yang dilaksanakan karena telah mencapai target kriteria keberhasilan yang ditetapkan.

Berdasakan ketercapaian hasil nilai angket dan observasi motivasi yang melampaui kriteria keberhasilan disimpulkan bahwa implementasi model pembelajaran Find Someone Who dan Timed Pair Share dapat meningkatkan motivasi belajar siswa. Hasil penelitian ini sejalan dengan penelitian yang dilaksanakan oleh Nurhaniyah,dkk (2015). Nurhaniyah, dkk (2015) menyatakan bahwa implementasi model Find Someone Who dapat meningkatkan motivasi belajar. Peningkatan motivasi yang terjadi dikarenakan siswa tertarik belajar dengan menggunakan model pembelajaran Find Someone Who dan Timed Pair Share. Menurut Masikem, dkk (2016) bahwa mempelajari pengetauhan dengan menggunakan model pembelajaran kooperatif membuat siswa tidak bosan. Penerapan cara belajar yang baru melalui pelaksanaan model pembelajaran Find Someone Who dan Timed Pair Share membuat siswa menjadi penasaran dan menambah fokus dalam belajar.

Peningkatan persentase lembar observasi motivasi dan angket motivasi menunjukkan bertambahnya semangat dan keseriusan siswa dalam belajar IPS. Keseriusan siswa dalam belajar IPS menumbuhkan sikap kepercayaan diri siswa. Bentuk kepercayaan diri siswa ditunjukkan dengan sikap keseriusan siswa dalam membandingkan jawaban, antusiasme siswa dalam memperhatikan dan menanggapi pembahasan jawaban, berani berpendapat, tidak ragu dalam menjawab pertanyaan. Hal tersebut sejalan dengan pendapat Schunk (2012) bahwa siswa yang memiliki motivasi dalam belajar memiliki ciri-ciri (1) serius dalam mencari informasi materi pembelajaran, (2) siswa mendengar dengan seksama informasi pengetauhan dari teman, (3) siswa bertanya pada guru dan teman apabila materi yang belum siswa pahami, dan (4) siswa akan berusaha menghafal materi yang diajarkan.

Dalam penelitian ini, siswa berlatih mendengarkan pendapat dan memuji pendapat siswa yang lain. Siswa tidak terlihat menyalahkan jawaban dari siswa yang lain. Siswa berlatih menghargai perbedaan jawaban dari temannya. Situasi yang positif selama pembelajaran yang dibiasakan kepada siswa berupa toleransi dan tidak mencela perbedaan jawaban menyebabkan siswa nyaman dan merasa dihargai oleh temannya. Siswa yang pendapatnya merasa dihargai oleh temannya akan meningkatkan semangat, tanggung jawab, motivasi, menambah keterlibatan dalam pembelajaran dan belajar lebih banyak. Hal ini sesuai dengan pendapat Wang (2012) yang berpendapat bahwa dampak positif menerapkan pembelajaran kooperatif membuat pembelajaran menjadi menyenangkan bagi siswa. Hal tersebut karena siswa mendapatkan pengalaman-pengalaman baru dari interaksi dengan temannya. Siswa termotivasi siswa untuk menggali lebih banyak pengetauhan. Goodyear, dkk (2014) dalam penelitiannya menyebutkan bahwa penerapan pembelajaran kooperatif mampu meningkatkan self-esteem dan motivasi belajar siswa.

\section{Implementasi Model Pembelajaran Find Someone Who dan Timed Pair Share untuk Meningkatkan Hasil Belajar IPS}

Hasil belajar dipandang sebagai alat evaluasi atas kemajuan dan ketertinggalan siswa dalam menguasai materi yang diajarkan (Dimyati \& Mudjiono, 2006). Hasil belajar adalah kemampuan yang diperoleh setelah siswa mengalami pengalaman belajar. Hasil belajar pada penelitian ini terfokus pada hasil belajar kognitif muatan IPS kelas V SD. Pengukuran hasil belajar dilakukan melalui tes tulis. Tes tulis diberikan siswa pada setiap akhir siklus.

Hasil belajar klasikal IPS pada pratindakan mencapai 40\% dengan kategori kurang. Hasil belajar klasikal pratindakan belum mencapai kriteria keberhasilan yang ditetapkan yaitu $\geq 80 \%$. Hasil belajar IPS pada pratindakan terdapat 15 siswa yang tuntas dan 22 siswa yang tidak tuntas. Hasil belajar klasikal pada siklus I mencapai $70 \%$ dengan kategori baik. Pada hasil belajar IPS pada siklus I terdapat 26 siswa yang tuntas dan 11 siswa yang tidak tuntas. Hasil belajar klasikal siklus I mengalami peningkatan daripada hasil belajar pratindakan dengan kenaikan sebesar 30\%. Hasil belajar klasikal pada siklus I belum mencapai kriteria keberhasilan yang ditetapkan. Hasil belajar klasikal pada siklus II mencapai 89\% dengan kategori sangat baik. Pada hasil belajar IPS pada siklus II terdapat 33 siswa yang tuntas dan empat siswa yang tidak tuntas. Hasil belajar klasikal pada siklus II mengalami peningkatan daripada siklus I dengan kenaikan sebesar 19\%. Hasil belajar pada siklus II menunjukkan keberhasilan dalam penelitian yang dilaksanakan karena telah mencapai target kriteria keberhasilan yang ditetapkan.

Keberhasilan penerapan model pembelajaran Find Someone Who dan Timed Pair Share dalam meningkatkan hasil belajar pada kelas VB SDN Pakunden 2 Kota Blitar sejalan dengan hasil penelitian Kurnia, dkk (2017) dan Marlina, dkk (2016). Kurnia, dkk (2017) menyatakan bahwa implementasi model pembelajaran Find Someone Who dapat meningkatkan hasil belajar. Marlina, dkk (2016) menyatakan dalam penelitiannya bahwa implementasi model pembelajaran Find Someone Who dapat meningkatkan hasil belajar IPS. Peningkatan hasil belajar IPS disebabkan karena tertarik belajar dengan menggunakan model pembelajaran Find Someone Who dan Timed Pair Share. Bukti ketertarikan siswa belajar dengan menggunakan model pembelajaran Find Someone Who dan Timed Pair Share adalah meningkatkannya aktivitas bekerja sama saling bertukar informasi dan jawaban bersama pasangannya. Dengan saling bertukar informasi dengan pasangannya, siswa yang berakademik tinggi merasa diuntungkan karena memperkuat pemahaman terhadap materi yang dipelajarinya serta melatih berkomunikasi dengan temannya. Siswa yang berakademik rendah yang mendengar jawaban dari temannya dapat merevisi jawabannya yang masih salah. Hal tersebut membuat siswa mudah mengingat materi dan menyerap materi yang diajarkan. Hal ini sejalan dengan pendapat Yamarik (2007) berpendapat bahwa pembelajaran kooperatif membantu siswa yang berprestasi rendah untuk 
memahami materi pembelajaran, sedangkan pembelajaran kooperatif bagi siswa yang berprestasi tinggi membantu meningkatkan keterampilan berkomunikasi Selaras dengan pandapat Fajar (2017) bahwa pembelajaran kooperatif membantu siswa memperoleh pemahaman yang lebih tinggi terhadap materi pembelajaran. Ames (1992) berpendapat bahwa pembelajaran secara berpasangan atau kelompok bermanfaat untuk menciptakan situasi yang lebih berorientasi untuk membimbing siswa untuk menguasai materi yang diajarkan.

\section{SIMPULAN}

Berdasarkan hasil penelitian yang telah dilaksanakan, disimpulkan bahwa implementasi model pembelajaran Find Someone Who dan Timed Pair Share dilaksanakan sangat baik oleh guru dan siswa. Hasil observasi keterlaksanaan pembelajaran oleh guru dan siswa mampu mencapai kriteria keberhasilan yang ditentukan. Hasil observasi keterlaksanaan pembelajaran oleh guru mengalami peningkatan dari siklus I ke II. Hasil observasi keterlaksanaan pembelajaran pada siklus I mencapai $73,4 \%$, sedangkan observasi hasil keterlaksanaan pembelajaran oleh guru pada siklus II mencapai $88,9 \%$. Hasil observasi keterlaksanaan pembelajaran oleh siswa mengalami peningkatan dari siklus I ke II. Hasil observasi keterlaksanaan pembelajaran oleh siswa pada siklus I mencapai 71\%, sedangkan hasil observasi keterlaksanaan pembelajaran oleh siswa pada siklus II mencapai 87,3\%. Implementasi model pembelajaran Find Someone Who dan Timed Pair Share dapat meningkatkan motivasi belajar. Hasil observasi motivasi dan nilai angket mampu mencapai kriteria keberhasilan yang ditentukan. Hasil observasi motivasi mengalami peningkatan dari siklus I ke II. Hasil observasi motivasi pada siklus I mencapai 71,5\%, sedangkan hasil observasi motivasi pada siklus II mencapai $84,7 \%$. Hasil nilai angket motivasi mengalami peningkatan dari pratindakan sampai siklus II. Nilai angket motivasi pada pratindakan mencapai 58,3\%, siklus I mencapai $75,1 \%$, dan siklus II mencapai 88,2\%. Implementasi model pembelajaran Find Someone Who dan Timed Pair Share dapat meningkatkan hasil belajar IPS. Tes hasil belajar IPS mampu mencapai kriteria keberhasilan yang ditentukan. Hasil belajar IPS pada pratindakan mencapai 40\%, siklus I mencapai 70\%, dan siklus II mencapai $89 \%$.

Berdasarkan hasil penelitian, maka saran yang dapat diajukan oleh peneliti adalah, guru disarankan membelajarkan siswa dengan menggunakan model kooperatif Find Someone Who dan Timed Pair Share. Kedua model membuat siswa aktif mengonstruksi pengetauhan dan menambah kepercayaan diri siswa sehingga membuat siswa lebih termotivasi dalam belajar untuk meningkatkan hasil belajar. Guru disarankan mampu menjelaskan model pembelajaran Find Someone Who dan Timed Pair Share secara rinci. Hal ini agar siswa mampu memahami dan menjalankan langkah-langkah model pembelajaran dengan benar. Guru sebaiknya aktif membimbing siswa yang mengalami kesulitan dan memberi perhatian kepada siswa yang kurang bersunggu-sungguh dalam belajar. Guru sebaiknya membentuk kelompok belajar dengan skala kecil dengan tingkat akademis dan jenis kelamin yang seimbang. Hal ini efektif menciptakan suasana pembelajaran kondusif dan saling bekerjasama.

\section{DAFTAR RUJUKAN}

Ames, C. (1992). Classrooms: Goals, Structures, and Student Motivation. Journal of Educational Psychology, 84(3), 261

Christophel, D. M. (1990). The Relationships Among Teacher Immediacy Behaviors, Student Motivation, and Learning. Communication Education, 39(4), 323-340

Dimyati \& Mudjiono. (2006). Belajar dan Pembelajaran. Jakarta: Rineka Cipta.

Effendi, A, Soetjipto, B. E., \& Widiati, U. (2016). The Implementation of Cooperative Learning Model TSTS and Carousel Feedback to Enhance Motivation and Learning Outcome for Social Studies. Journal of Research \& Method in Education (IOSR-JRME), 6(3), 131-136

Fajar, M. T. A, Soetjipto, B. E., \& Amirudin, A. (2017). The Implementation of Cooperative Learning Model Carousel Feedback and Two Stay Two Stray To Enhance Social Skill and Learning Outcome of the Ninth Grade Students. 7(3), 7984

Goodyear, V. A, Casey, A, \& Kirk, D. (2014). Hiding Behind The Camera: Social Learning Within The Cooperative Learning Model To Engage Girls In Physical Education. Sport, Education and Society, 19(6), 712-734

Gunawan. (2013). Pendidikan IPS: Filosofi,Konsep,dan Aplikasi. Bandung: Alfabeta.

Kagan, S., \& Kagan, M. (2009). Kagan Cooperative Learning. San Clemente: Kagan Publishing.

Keller. (2010). Motivational Design for Learning and Performance (The ARCS Model Approach). New York: Springer Science Business Media.

Kim, J, Kim, M, \& Svinicki, M. D. (2012). Situating Students Motivation In Cooperative Learning Contexts: Proposing Different Levels of Goal Orientations. Journal of Experimental Education, 80(4), 352-385

Kurnia, N. Degeng, I. N.S., \& Soetjipto, B. E. (2017). The Implementation of Find Someone Who and Two Stay Two Stray Models to Improve Students' Self-Efficacy and Social Studies Learning Outcomes. IOSR Journal of Research \& Method in Education (IOSRJRME), 07(03), 66-70

Marlina, L, Soetjipto, B. E, \& Hadi, S. (2016). The Implementation of Rally Coach and Find Someone Who Models to Enhance Social Skill and Social Studies Learning Outcomes. IOSR Journal of Research \& Method in Education, 6(3), 86-92 
Masikem., Soetjipto, B. E., \& Sumarmi. (2016). The Implementation of Cooperative Learning Model Talking Chips and Quick on the Draw to Enhance Motivation and Social Studies Learning Outcome. Journal of Research \& Method in Education (IOSR-JRME), 6(3), 33-39

Nurhaniyah, B., Soetjipto, B. E., \& Hanurawan, F. (2015). The Implementation of Collaborative Learning Model Find Someone Who and Flashcard Game to Enhance Social Studies Learning Motivation for the Fifth Grade Students. Journal of Education and Practice, 6(17), 166-171.

Ozturk., \& Akkas. (2013). The Effect of Cooperative Learning Activities on Anxiety and Motivation in Multilevel Adult Classes. Hacettepe Universitesi Egitim Fakultesi Dergisi-Hacettepe University Journal of Education, 28(3), 357-373

Purwaningrum, M. D., Soetjipto, B. E., \& Untari, S. (2017). The Implementation of Cooperative Learning Model Quiz-Quiz Trade and Inside-Outside Circle to Improve the Students' Social Skills and Learning Outcomes. International Journal of Academic Research in Business and Social Sciences, 7(6), 473-486

Scharle, A., \& Szabo, A. (2005). Learner Autonomy, A Guide To Developing Learner Responsibility. United Kingdom: Cambridge University Press.

Schunk, D. H. (2012). Motivasi dalam Pendidikan (Teori, Penelitian, dan Aplikasi). Jakarta: PT Indeks.

Wang. (2012). Effects of Cooperative Learning on Achievement Motivation of Female University Students. Asian Social Science, 8(15), 108-114

Yamarik. (2007). Does Cooperative Learning Improve Student Learning Outcomes ? Journal of Economic Education, 3(38), 259-277. 